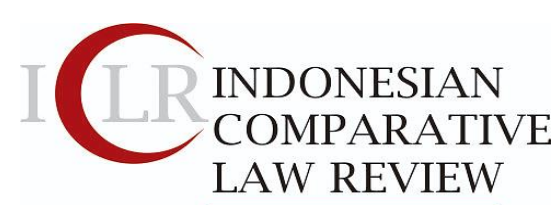

Volume 2 No 1, December 2019 P-ISSN: 2655-2353, E-ISSN: 2655-6545
Article Info:

Received : 23-10-2019

Revised : 13-05-2020

Accepted : 28-05-2020

\section{E-Hailing Transportation and the Issue of Competition in Indonesia}

\section{Rizaldy Anggriawan}

Financial and Economic Law Department, Asia University, Taiwan

Email: 108136043@live.asia.edu.tw

\section{Abstract}

The emergence of ride-sharing concept through the e-hailing application is considered as a form of alternative to filling the gap on the demand for public transportation as well as reducing the number of vehicles on the road. E-hailing is the process of requesting a transportation vehicle by means of computers, cell phones or other electronic devices. Unfortunately, despite the massive growth of e-hailing transportation and its positive impact in Indonesia, numerous issues have also appeared along with the growth of e-hailing. There are several indications that $e^{-}$ hailing companies are waging a discount, fare, and promotion wars. There is potential unfair business competition in Indonesia in the form of predatory pricing in the e-hailing motorcycle taxi industry (ojol) which is participated by two market players namely Go-Jek and Grab. The mode is by applying promotion fare as low as possible with the intention to eliminate their competitors' business in the relevant market. And as a result of that, the winner will be monopolizing the market and harming the ecosystem in it. The paper examines the questions on whether or not the competition law beneficial for the e-hailing industry? And, how successful has the Indonesian competition policy been in creating an equal playing field for all http://dx.doi.org/10.18196/iclr.2116 transportation industry parties? As the result of the paper, it shows that the existence of e-hailing industry is threatened. As the e-hailing companies are trapped in cash-burning practice. Therefore, the competition law is regarded as beneficial for the e-hailing industry to control the competition and fair business process among the competitors. Moreover, the Indonesian government needs to prudently watch on the issue and formulate the best resolution for all parties, particularly regarding the competition policy and its enforcement.

Keywords: competition law, e-hailing, regulation, unfair business, predatory pricing

\section{Introduction}

With the rapid advancement of technology and the development of economic in Indonesia, people might gain and lose several aspects of their quality of life. The connection between these two is inevitable. The increasing migration and rapid urbanization have created great issue on the current population concerning life quality. Thus, traffic congestion nowadays has become one of the issues in the quality of life among the urban population. At present, as the necessity of owning a vehicle, the number of private-owned vehicle has tremendously increased. Based on certain research, it indicates that the main motivation of owning and driving a car is due to the mobility factor. Mobility means that the owner of private vehicle could go around easily to any destination they want to go without any hindrance. ${ }^{1}$ In addition, another research exposed that the tendency of people to use and own private vehicles is -

1 Kusuma, C.A., Multifiah., \& Syafitri, W. (2018). Analisis Korelasi Mobilitas Penduduk dan Sosioekonomi Terhadap Kepemilikan Kendaraan. Warta Penelitian Perhubungan, 30(2): 103. 
due to the inaccessibility to an effective and via mobile phone applications. It is applicable efficient public transportation facility. ${ }^{2}$ In to both Android and iOS. In terms of service particular urban areas, a study has shown commitment, at most times the conventional that with efficient and proper public taxi and bike drivers are less commitment transportation facilities as well as the transit than the e-hailing taxi \& bike drivers as the systems, the level of car ownership increment could be significantly reduced. ${ }^{3}$

The emergence of ride-sharing model is considered as a sort of alternative for transportation to fill the gap on the demand for taxis as well as reducing the number of vehicles on the road. The idea is to have carsharing, so there will be more than one person travels in a car. The e-hailing model is massively welcomed by many city residents as a breakthrough that provides them benefits through a reduction of waiting time and transportation costs to pick a ride since frequently the existence of public transportation is not adequate to supply the passengers demand. ${ }^{4}$

E-hailing is the process of requesting a transportation vehicle by means of computers, cell phones or other electronic devices. ${ }^{5}$ E-hailing applications are available

2 Susantono, B., Santosa, W., \& Budiyono, A. (2011). Kepemilikan Kendaraan dan Pola Perjalanan di Wilayah Jabodetabek. Jurnal Transportasi, 11(3): 155.

${ }^{3}$ Jais, A.S., \& Marzuki, A. (2018). Urban Mobility Using E-Hailing in the Historic City of Melaka, Malaysia: Preliminary Findings. Paper presented at the Seventh International Conference on Built Environment in Developing Countries. Kuching Sarawak, Malaysia. prior incline to decline consumers in peak hours and sometimes offer high rate fare, thus e-hailing transportation became more popular in Indonesia due to those factors. ${ }^{6}$

Ride-sharing was first presented by Garrett Camp and Travis Kalanick in San Francisco, the United States of America through the launching of Uber Cab in March 2009 which provides E-hailing services utilizing cell phone application that was publicly launched in 2011.7 This ride-sharing model has spread across the world. Meanwhile, in Indonesia, it started with Gojek in 2011. The launch of such e-hailing has transformed the conventional taxi model. At the point of time, Go-jek and other e-hailing vendors such as Grab and Ojesy became an interesting phenomenon in Indonesian society. ${ }^{8}$

At the present time, the app allows customers to register a ride and issue the ebill at anytime and anywhere as their favor. This has made convenient for the consumers to travel around, besides it settled the unemployment issues by employing e-hailing drivers. For most consumers, e-hailing has widely been comprehended as great technology advancement, for that it provides

4 Teo, B.C., Mustaffa, M.A., \& Rozi, A.I.M. (2018).

"To Grab or Not to Grab?: Passenger Ride Intention towards E-Hailing Services". Malaysian Journal of Consumer and Family Economics, 21: 153. 5 Vivoda, J., Harmon, A., Babulal, G., \& ZikmundFisher, B. (2018). E-hail (Rideshare) Knowledge, Use, Reliance, and Future Expectations among Older Adults. Transportation Research Part F

uture_Expectations_among_Older_Adults.

[Accessed on May 13, 2020 at $12.21 \mathrm{pm}$ ].

${ }^{6}$ Ruangkanjanases, A., \& Techapoolphol, C. (2018).

"Adoption of E-hailing Applications: A Comparative Study between Female and Male Users in Thailand". Journal of Telecommunication, Electronic and Computer Engineering, 10(1-10): 43.

${ }^{7}$ Matherne, B.P \& O'toole, J. (2017). "E-hailing: Aggressive Management for Growth". The Case Journal, 13(4):561.

Traffic Psychology and Behaviour. Available from: 8 Natadjaja, 1 \& Setyawan, P.B. (2016). "Creating https://www.researchgate.net/publication/3244 Community through Design: The Case of Go-Jek 51095_E-

hail_Rideshare_Knowledge_Use_Reliance_and_F

Online". International Journal of Cultural and Creative Industries, 4(1):19. 
better choices and cheaper fares. E-hailing was enacted the day after and implemented improved the traditional economic model in mid-2019. The revision covers fare limit, into a sharing economy model, thus the minimum service standards, and suspension platform which links up users and providers implementation. ${ }^{12}$ The new regulation is a will enable people to share their goods and substitute for the Ministry of Transportation services. In recent years, e-hailing has played Regulation No. 108 Year 2017 which is a big role in revolutionizing the private revoked by The Supreme Court (MA) in 2018. transport market. ${ }^{9}$

Unfortunately, despite the massive growth of e-hailing transportation and its positive impact in Indonesia, numerous issues have also appeared along with the growth of e-hailing. It faced several big protests by many parties, such as the conventional taxi whose income has been seriously disrupted by the existence of ehailing. ${ }^{10}$ This is as the company began to expand massive business penetration. For conventional taxi drivers, e-hailing companies such as Go-Jek and Grab reasonably provided mounting threats with the existence of Go-Car and Grab-Car. In order to counter such e-hailing companies, demonstrators staged large-scale protests not only in Jakarta but also in other big cities. ${ }^{11}$

However, in order to defuse the looming tension, the Indonesian Ministry of Transportation recently released a new regulation regarding e-hailing transportation. It is defined in the Ministry of Transportation Regulation No. 118 Year 2018 on the Special Rental Services. The regulation was initiated and signed by the Minister of Transportation Budi Karya Sumadi in December 2018 and

9 Todd, L., Amirullah, A., \& Xing, C.H. (2018). “Ehailing Regulations: Striking the Right Balance". Policy Ideas, 57: 4.

10 Azzuhri, A.A., Syarafina, A., Yoga, F.T., \& Amalia, R. (2018). "A Creative, Innovative, and Solutive Transportation for Indonesia with Its Setbacks and How to Tackle Them: A Case Study of the Phenomenal GOJEK". Review of Integrative Business and Economics Research, 7(1):60.

ian

11 Kartajaya, H \& Huan, H.D. (2019). Asian Competitors Case Book: Marketing for Competitiveness in the Age of Digital Consumers. Singapore: World Scientific Publishing, p. 106. Also, this new policy is highly expected to stir healthier competition among conventional and e-hailing transportation companies.

The paper aims to answer the questions on whether or not the competition law beneficial for the e-hailing industry? And, how successful has the Indonesian competition policy been in creating an equal playing field for all transportation industry parties?

\section{Analysis and Results}

2.1. Indonesian E-hailing Competition Policy

\subsubsection{Is Competition Law Beneficial for E-} hailing Industry?

Modern competition law is a form of government intervention in the economy that is principally intended to increase the economic growth which will affect the Indonesia's GDP o positive trend. More specifically, competition law is intended to regulate the aggregation of market power. Market power is a result of imperfect competition and a cause of market failure. Increased market power provides market participants with an increased ability to influence the market price for their own profit-maximizing benefit, to the detriment of market efficiency. Competition law assumes that the behavior of market participants must be regulated so that they do not seek to

12 The Inside Stories. (2018). Indonesia Revises Online Transportation Rule. Available from: https://theinsiderstories.com/indonesia-revisesonline-transportation-rule/. [Accessed September $28,2019$ at $6.34 \mathrm{pm}]$. 
increase their individual of collective market power by engaging in anti-competitive behavior, known as 'behavioral regulation'. ${ }^{13}$

The competition law economic efficiency objectives can be supplemented by distribution objectives. The objective of the distribution is diverse and often controversial, but it is intended to produce a more equitable distribution of welfare in society. Contemporary competition laws often seek to reconcile the inherent strains between the economic efficiency objective and fairness of distribution. Furthermore, competition law has indirect welfare benefits. Competition law may create an environment conducive to the adoption of complementary competition policies. Deregulatory competition policies are intended to reduce excessive governmental regulation that may otherwise reduce competition or distort market incentives. Such competition policies may materially contribute to economic growth and increased social welfare. The benefits of such competition policies have been empirically quantified and are usually significant (Taylor, 2006).

When discussing the e-hailing issues, some people may have a question on whether and how competition law is relevant to Ehailing practices. Basically, the competition law would help people to understand and analyze better on E-hailing business. Practically, E-hailing applies a business concept that is involving two indirect networks between users and drivers. That is to say that E-hailing's business evolved not only because it improved the utilization of driving skills and enhanced the use of unutilized vehicle, but also because it relished the reciprocal fact that many users will be definitely attracted by a great number of drivers and vice-versa. ${ }^{14}$ The growth and

13 Taylor, M. (2006). International Competition Law: A New Dimension for the WTO?. Cambridge: Cambridge University Press, p. 16.

14 Evans, D.S., \& Noel, M. (2005). “Defining Competition Markets When Firms Operate Two- existence of the e-hailing business model are supported by the fact that it exploited the interdependencies that occurred between two different demands namely, the driving and transportation demand, which is between the users and drivers.

Furthermore, the E-hailing platform has an interoperable software system that is flexible to create a new innovative business model. As a result of that E-hailing could simply expand its business product by linking other goods and services with the platform, as applied by Go-Food, Grab Food, Uber Eat, Go-Box, Grab Express, etc. Further, as the technology and novel functionalities offered by E-hailing companies. Thus, it makes the conventional taxi companies is less valuable than the new competitors offer. ${ }^{15}$ However, according to a competition viewpoint, those facts may create several concerns. Although, the digital market competition is extremely dynamic as the platform offers a new and innovative models, ${ }^{16}$ some people still have worries that e-hailing companies may develop new profitable services with forestall plans that create exclusivity.

In fact, the E-hailing companies may provide low-cost fare for the consumers rather than as prevailed by the conventional taxi companies. Thus, the consumers preferably choose E-hailing transportation in order to travel to their intended destination. This phenomenon has created an extreme Sided Platform". Columbia Business Law Review, 3: 109.

15 Kovacic, W.E. (2012). Competition in High-Tech Industries: Improving the Federal Competition Joint Venture. George Mason Law Review, 19(5): 1100.

16 Colangelo, M., \& Maggiolino, M. (2017). Ehailing: A New Challenge for Regulation and Competition Law?. Market and Competition Law Review. Available from: https://www.academia.edu/35236191/e-

hailing_a_new_challenge_for_regulation_and_co mpetition_law. [Accessed on October 4th, 2019]. 
discrepancy between both companies. Based of Ministry of Transportation Regulation No. on those above facts, it concludes that 12 of 2019 concerning Safety Protection of competition law is beneficial for the e-hailing Motorcycle Users Used for Public Interest industry to control the competition and fair and the Decree of the Minister of business process among the competitors. Transportation of the Republic of Indonesia Moreover, the Indonesian government needs Number KP 348 of 2019 concerning to watch prudently on the issue and Guidelines for Calculating Fees for the Use of formulate the best resolution for all parties, Motorbike Services Used for Public Interest particularly regarding the competition policy through the Application.

and its enforcement.

Although the decree has regulated the

\subsubsection{E-hailing Facts and Competition Poli-} cies

The environment of business practice is currently filled with numerous unhealthy business behaviors. In Indonesia, some entrepreneurs tend to foster incentives to gain market power and gain flexibility in controlling prices. In creating these market forces, entrepreneurs take any means that potentially harm the competitors, such as imposing a market restriction, creating barriers to entry, entering into collusive agreements to regulate prices, limiting the output, controlling the market, and carrying out other anti-competitive practices. ${ }^{17}$ The term "entrepreneur" is regulated in Article 1 Section 5 of Law No. 5 Year 1999, namely:

"Entrepreneur is an individual person or a company, in the form of a legal or nonlegal entity established and domiciled or engaged in activities within the legal territory of the Republic of Indonesia, conducting various kinds of business activities in the economic sector through contracts, both individually or collectively."

Business competition administrators were demanded to be aware with the indication of unfair business competition behavior particularly on the issue of e-hailing transportation. Moreover after the enactment

17 Febrina, R.. (2017). "Dampak Kegiatan Jual Rugi (Predatory Pricing) yang Dilakukan Pelaku Usaha dalam Perspektif Persaingan Usaha". Jurnal Selat, 4(2): 235. fare issue, yet still there are several indications that e-hailing companies are waging a discount, fare, and promotion war. Thus, the Indonesian Business Competition Supervisory Commission (KPPU) must be able to prevent the e-hailing companies to perform a fare war. KPPU is the only one authorized institution and has a role to supervise and enforce their power. While on the other hand, the Ministry of Transportation may not critically be involved in the issue. Since the authority of the Ministry of Transportation is to stipulate regulations only and will not eligible to intervene in terms of unfair business practice enforcement.

With the current fact, the existence of the e-hailing industry is threatened. As the ehailing companies are trapped in cashburning practice. Thus, one who has not equipped with a great number of capital will lose. And as a result of that, the winner will be monopolizing the market and harming the ecosystem in it. Typically, if a monopoly occurs, one enterprise will control the market and the price. Thus, consumers no longer have a choice. And this will be a setback for the government and industry. As it has already occurred in Singapore and the Philippines. ${ }^{18}$ The fare will be very expensive,

18 Liputan 6. (2019). KPPU Diminta Waspadai Praktik Monopoli di Bisnis Ojek Online. Available from:

https://www.liputan6.com/bisnis/read/3961099 /kppu-diminta-waspadai-praktik-monopoli-di-

bisnis-ojek-online. [Accessed on October 11, 2019 at $5.12 \mathrm{pm}]$. 
while services will deteriorate due to the absence of alternatives. Hence, in essence, consumers become victims.

And in the end, if the consumers consider the riding fare is too expensive, then they will return to private or conventional transportation even though it is less efficient in terms of time and service. It threatens the existence of millions of e-hailing partners who currently count their incomes from such services. Therefore, a healthy competition should be a competition of innovation, technology and creativity. And not a competition in terms of providing the highest fare subsidies, especially in the form of exaggerated promotion. Although it can be profitable in the short term, but it will be deadly in the long run.

For example, there is a potential unfair business competition in Indonesia in the form of predatory pricing in the e-hailing motorcycle taxi industry (ojol) which involved by two applicators namely Go-Jek and Grab. The mode is by applying promotion fare as low as possible. The predatory pricing is regulated in the Article 20 of Law No. 5 Year 1999 which is said:

"Entrepreneurs are prohibited from
supplying goods and/or services by
selling without making any profits or by
setting a very low price with the
intention to eliminate or end their
competitors' business in the relevant
market, thus causing monopolistic
practices and/or unfair business
competition."

The traditional theory of predatory pricing is straightforward. At the initial stage, the predatory companies will offer lower fare than the competitor price. As a result, the competitor must inevitably lower its fare below the average cost. Thus, the competitor will lose the profit on each unit utilized by passengers. In fact, if the competitor fails to offer lower fare, they will gradually lose their market share. On the other hand, if the competitor offers lower fare until below its average cost, they will eventually go bankrupt. Once the predatory companies have successfully rid of the competitor from the market, the predatory company will raise their fare and rewarding themselves for the lost money when they committed predatory pricing. And in the end, the predatory companies then will monopolize the market and have the freedom to manage public transportation fares. ${ }^{19}$ As it is reasonable for predator companies just like any sort of other investment to consider the present losses will be rewarded by future profits. ${ }^{20}$

The conservative outlook was later complemented by the opinion that the prospective profits to the predator companies were not restricted to upcoming profits in the market area where it predated. The predatory activity may be seen as a reputation investment which might pay a dividend by deterring the competitors to enter the market. 21 Therefore, these effects consequently will increase the advantages from the early predatory event. Scherer refers to it as:
"... the demonstration effect that sharp price cutting in one market can have on the behaviour of actual or would be rivals in other markets. If rivals come to fear from a multimarket seller's actions in Market $A$ that entry or expansion in Markets $B$ and $C$ will be met by sharp price cuts or other rapacious responses, they may be deterred from taking aggressive actions there. Then the conglomerate's expected benefit from

\footnotetext{
${ }_{19}$ DiLorenzo, T. J. (1991). “The Myth of Predatory Pricing". Cato Institute Policy Analysis, 169: 1.

20 Organisation for Economic Co-Operation and Development. (1989). Predatory Pricing. Retrieved from:

http://www.oecd.org/competition/abuse/23756 61.pdf. [Accessed on October 12, 2019 at 3.43 pm]. 21 Posner, R.A. (1976). Antitrust Law: An Economic Perspective. Chicago: University of Chicago, p. 185-186.
} 
predation in Market $A$ will be supplemented by the discounted present value of the competition-inhibiting effects its example has in Markets B and C." 22

Further, the extensive economic and legal literature has developed specific standards to determine whether or not a company is engaging in predatory pricing practices. One of the most influential literature on this case is the Areeda and Turner test. They consider that the standard for determining this practice can be seen when a company sets prices below its shortterm marginal costs. However, because the data on short-term marginal costs is difficult to obtain, they suggest using Average Variable Cost (AVC) data as a proxy. The logic underlying this determination is that no company has ever benefited when operating under conditions where prices are lower than the short-term marginal costs. ${ }^{23}$ Therefore, the pricing below the short-term marginal cost is unreasonable without the prospect of long-term profits.

Hasanuddin University economist as well as the former KPPU Chairman in the period of 2015-2018, Muhammad Syarkawi Rauf sees the possibility of this practice in the ojol market. He said:

"There is an average variable cost, they sell below that, their first attempt is to increase market share by driving out competitors, eventually they will become a monopolist. When a competitor leaves the market, they will raise the fare incredibly high, and the consumer will be exploited." 24

22 Scherer, F.M. (1980). Industrial Market Structures and Economic Performance. Boston: Houghton Mifflin Company, p. 338.

23 Areeda, P., \& Turner, D.F. (1975). "Predatory Pricing and Related Practices under Section 2 of the Sherman Act". Harvard Law Review, 88(4): 700703.

24 Bisnis.com. (2019). Wah, Ada Persaingan Tak Sehat dalam Industri Ojek Online? Available from: https://ekonomi.bisnis.com/read/20190520/98/
It will take a long time in the process of settling the predatory pricing case, bearing in mind that KPPU can only take the action when one of the competing companies actually leaves the market. In addition, the rules regarding predatory pricing are contained Article 20 in Law No.5 Year 1999 concerning Prohibition of Monopoly Practices and Unfair Business Competition. The sanctions are limited to a maximum fine of Rp25 billion and the most severe sanction is such companies will be banned to perform their business in the relevant industry within a certain period.

Comparing to what occurred in Singapore, where the government imposed a penalty on the ride-hailing company Grab of S\$13 million over the agreement to acquire Uber at the end of March 2018. Grab announced that it had acquired Uber business operations in Southeast Asia. As a return, Uber pocketed a 27.5 percent stake in Grab. ${ }^{25}$ The fine was carried out because the government considered the acquisition of the business had violated the rules of business competition. A business merger between the two is considered will destruct the business climate. The Singapore government considers the business agreement will have an impact on the application of the fare and is considered as an obstacle for business competition.

The Competition and Consumer Commission of Singapore (CCCS) is the regulator which was conducted an investigation upon the acquisition of the business. In the conclusion of the investigation, the commission said the business merger substantially reduced the business competition in Singapore.

924905/wah-ada-persaingan-tak-sehat-dalam-

industri-ojek-online. [Accessed on October 12, 2019 at $2.03 \mathrm{pm}]$.

25 Acquisition of Uber's Southeast Asian business by Grab and Uber's acquisition of a 27.5 per cent stake in Grab. 500/001/18 CSSS. 142. The Competition and Consumer Commission of Singapore (2018). 
Moreover, Grab fares were reported to have risen 10 to 15 percent after a business deal. On the other hand, the driver must also face a reduction in points received and find it more difficult to redeem bonuses. Furthermore, the merger even inhibits potential business and gives the impression of business exclusivity for Grab. Drivers and passengers no longer have the option to use the services of other companies. ${ }^{26}$

The acquisition of Uber assets by Grab in Southeast Asia has a significant impact on competition in the online application-based transportation industry in ASEAN countries, including Indonesia. In the case of Singapore and other ASEAN countries, the acquisition of Uber assets by Grab has an impact on the domination of the online application-based transportation market by Grab. Where Singapore Grab is the only player to dominate or monopolize the Singapore market. Before the acquisition, Uber and Grab competed for each other in the ASEAN market. It had a great impact on the market structure that was originally controlled by the two players with a market share of more than 70 percent, then it concentrated into a single player after the acquisition. Structurally, the market has changed from duopoly to monopoly market.

While in Indonesia, the e-hailing transportation market has also changed, from oligopoly to duopoly. The Indonesian market is still profitable as of the existence of Go-Jek as a relatively large local player so that the acquisition of Uber assets by Grab did not cause a change in market structure as occurred in Singapore.

In general, merger regulations in Singapore and Indonesia are considerably

${ }^{26}$ CNN Indonesia. (2018). Singapura Denda Rp137 M Atas Akuisisi Uber-Grab. Available from: https://www.cnnindonesia.com/teknologi/2018 0924142809-185-332720/singapura-denda-rp137m-atas-akuisisi-uber-grab. [Accessed on October $12,2019$ at $4.05 \mathrm{pm}]$. different, as the merger notification regime in Singapore adopted a voluntary merger notification. Singapore notification regime is modeled after the United Kingdom system, whereby when the notifications are made and submitted it is left entirely to the party who conducted the merger. Although the merger regime is voluntary, CCCS still has the authority based on its own initiative to conduct an investigation of merged businesses if CCCS suspects that the corporation action significantly reduces competition in the relevant market. Furthermore, CCCS also has the authority to impose and determine the penalty if it is proven that the acquisition violates articles in the Singapore Competition Act, particularly Article 54 of the Singapore Competition Act.

Where to date, CCCS has found that the takeover of Uber's assets by Grab has led to a loss of competition, allegedly a barrier to entry into the market, where Grab as a single player is suspected of making exclusive agreements with drivers, vehicle rental companies and taxi companies that limit cooperation with other e-hailing players who plan to enter the Singapore Market. ${ }^{27}$ In fact, there are three new e-hailing companies who have the potential to enter the online application-based transportation market in Singapore, namely Go-Jek from Indonesia, Jugnoo from India and Ryde, a local player from Singapore.

\section{Conclusion}

The competition law is beneficial for the e-hailing industry to control the competition and fair business process among the competitors. Moreover, the Indonesian government needs to prudently watch on the issue and formulate the best resolution for all

27 Sama.id. (2018). Predatory Pricing Pasca Grab Akuisisi Uber. Available from: http://www.sama.id/2018/07/09/predatorypricing-pasca-grab-akuisisi-uber/. [Accessed on October 12, 2019 at $4.32 \mathrm{pm}$ ]. 
parties, particularly regarding the competition policy and its enforcement.

In fact, the existence of the e-hailing industry is threatened. As the e-hailing companies are trapped in cash-burning practice. It is even worse as found the potential unfair business competition in Indonesia in the form of predatory pricing committed by the e-hailing motorcycle taxi industry (ojol) which involved by two applicators namely Go-Jek and Grab. The mode is by applying promotion fare as low as possible. The purpose is to increase market share by driving out competitors, eventually one of them will become a monopolist. When a competitor leaves the market, they will raise the fare incredibly high, and the consumer will be exploited.

In addition, the predatory pricing is regulated in Article 20 of Law No. 5 Year 1999. The article implies that entrepreneurs shall not sell products at very low prices, whose main purpose is to get rid of competing business actors from the market and also prevent potential competitors from entering the same market. However, the process of settling the predatory pricing case will take a long time, bearing in mind that KPPU can only take the action when one of the competing companies actually leaves the market.

\section{References}

Book:

Scherer, F.M. (1980). Industrial Market Structures and Economic Performance. Boston: Houghton Mifflin Company.

Kartajaya, H., \& Huan, H.D. (2019). Asian Competitors Case Book: Marketing for Competitiveness in the Age of Digital Consumers. Singapore: World Scientific Publishing.

Taylor, M. (2006). International Competition Law: A New Dimension for the WTO?
Cambridge: Cambridge University Press.

Posner, R.A. (1976). Antitrust Law: An Economic Perspective. Chicago: University of Chicago.

\section{Legislations:}

Law No.5 Year 1999 on Prohibition of Monopoly Practices and Unfair Business Competition

Ministry of Transportation Regulation No. 12 of 2019 on Safety Protection of Motorcycle Users Used for Public Interest

Ministry of Transportation Regulation No. 118 Year 2018 on the Special Rental Services

Ministry of Transportation Regulation No. 108 Year 2017 on Non-Route People Public Transportation

Decree of the Minister of Transportation of the Republic of Indonesia Number KP 348 of 2019 on Guidelines for Calculating Fare for the Use of Motorbike Services Used for Public Interest through the Application

Singapore Competition Act

\section{Court Decision:}

Acquisition of Uber's Southeast Asian business by Grab and Uber's acquisition of a 27.5 per cent stake in Grab. 500/001/18 CSSS. 142. The Competition and Consumer Commission of Singapore (2018).

\section{Journal Articles:}

Azzuhri, A.A., Syarafina, A., Yoga, F.T., \& Reski Amalia. (2018). "A Creative, Innovative, and Solutive Transportation for Indonesia with Its Setbacks and How to Tackle Them: A Case Study of the Phenomenal GOJEK". Review of Integrative Business and Economics Research, 7(1).

Ruangkanjanases, A., \& Techapoolphol, C. (2018). "Adoption of E-hailing 
Applications: A Comparative Study Areeda, P., \& Turner, D.F. (1975). “Predatory between Female and Male Users in Thailand". Journal of Telecommunication, Electronic and Computer Engineering, 10(1-10).

Boon-Chui Teo, B-C., Mustaffa, M.A., \& Rozi, A.I.M. (2018). “To Grab or Not to Grab?: Passenger Ride Intention towards E-Hailing Services". Malaysian Journal of Consumer and Family Economics, 21.

Matherne, B.P \& O'toole, J. (2017). “E-hailing: Aggressive Management for Growth". The Case Journal, 13(4).

Kusuma, C.A., Multifiah., \& Syafitri, W. (2018). Analisis Korelasi Mobilitas Penduduk dan Sosioekonomi Terhadap Kepemilikan Kendaraan. Warta Penelitian Perhubungan, 30(2): 103.

Todd, L., Amirullah, A., \& Xing, C.H. (2018). "E-hailing Regulations: Striking the Right Balance". Policy Ideas, 57.

Natadjaja,L., \& Setyawan, P.B. (2016). "Creating Community through Design: The Case of Go-Jek Online". International Journal of Cultural and Creative Industries, 4(1).

Colangelo, M., \& Maggiolino, M. (2017). Ehailing: A New Challenge for Regulation and Competition Law?. Market and Competition Law Review. Available from: https://www.academia.edu/35236191 /E-

HAILING_A_NEW_CHALLENGE_FO R_REGULATION_AND_COMPETITIO N_LAW. [Accessed on October 4, 2019 at $9.34 \mathrm{am}]$.

Conway, M.W., Salon, D., \& King, D.A. (2018). Trends in Taxi Use and the Advent of Ridehailing, 1995-2017: Evidence from the US National Household Travel Survey. Urban Science Journal, 2(3). Pricing and Related Practices under Section 2 of the Sherman Act". Harvard Law Review, 88(4).

Febrina, R. (2017). "Dampak Kegiatan Jual Rugi (Predatory Pricing) yang Dilakukan Pelaku Usaha dalam Perspektif Persaingan Usaha". Jurnal Selat, 4(2).

Susantono, B., Santosa, W., \& Budiyono, A. (2011). Kepemilikan Kendaraan dan Pola Perjalanan di Wilayah Jabodetabek. Jurnal Transportasi, 11(3).

DiLorenzo, T.J. (1991). The Myth of Predatory Pricing. Cato Institute Policy Analysis, 169.

Vivoda, J., Harmon, A., Babulal, G., \& Zikmund-Fisher, B. (2018). E-hail (Rideshare) Knowledge, Use, Reliance, and Future Expectations among Older Adults. Transportation Research Part F Traffic Psychology and Behaviour. Available from: https://www.researchgate.net/publica tion/324451095_E-

hail_Rideshare_Knowledge_Use_Relian ce_and_Future_Expectations_among_O lder_Adults. [Accessed on May 13, 2020 at $12.21 \mathrm{pm}]$.

Kovacic, W.E. (2012). Competition in HighTech Industries: Improving the Federal Competition Joint Venture. George Mason Law Review, 19(5).

\section{Paper:}

Jais, A.S., \& Marzuki, A. (2018). Urban Mobility Using E-Hailing in the Historic City of Melaka, Malaysia: Preliminary Findings. Paper presented at the Seventh International Conference on Built Environment in Developing Countries. Kuching Sarawak, Malaysia.

Evans, D.S., \& Schmalensee, R. (2010). Failure to Launch: Critical Mass in Platform Businesses. Available from: https:/ / ssrn.com/abstract=1353502. 
[Accessed on October 4, 2019 at 10.13 am].

\section{Report:}

Organisation for Economic Co-Operation and Development. (1989). Predatory Pricing. Retrieved from: http://www.oecd.org/competition/ab use/2375661.pdf. [Accessed on October $12,2019$ at $3.43 \mathrm{pm}]$.

\section{Internet:}

Bisnis.com. (2019). Wah, Ada Persaingan Tak Sehat dalam Industri Ojek Online? Available from: https://ekonomi.bisnis.com/read/201 90520/98/924905/wah-adapersaingan-tak-sehat-dalam-industriojek-online. [Accessed on October 12, 2019 at $2.03 \mathrm{pm}]$.

CNN Indonesia. (2018). Singapura Denda Rp137 M Atas Akuisisi Uber-Grab. Available from: https://www.cnnindonesia.com/tekno logi/20180924142809-185-

332720/singapura-denda-rp137-m-atasakuisisi-uber-grab. [Accessed on October 12, 2019 at $4.05 \mathrm{pm}$ ].

Liputan 6. (2019). KPPU Diminta Waspadai Praktik Monopoli di Bisnis Ojek Online. Available from: https://www.liputan6.com/bisnis/rea d/3961099/kppu-diminta-waspadaipraktik-monopoli-di-bisnis-ojek-online. [Accessed on October 11, 2019 at 5.12 pm].

Sama.id. (2018). Predatory Pricing Pasca Grab Akuisisi Uber. Available from: http://www.sama.id/2018/07/09/pre datory-pricing-pasca-grab-akuisisiuber/. [Accessed on October 12, 2019 at $4.32 \mathrm{pm}]$.

Tempo. (2019). Grab, Gojek Respond to Ban on Online Ojek Discounts. Available from: https://en.tempo.co/read/1213997/gr ab-gojek-respond-to-ban-on-online- ojek-discounts. [Accessed on September $28,2019$ at $12.35 \mathrm{pm}]$.

The Inside Stories. (2018). Indonesia Revises Online Transportation Rule. Available from:

https://theinsiderstories.com/indonesi a-revises-online-transportation-rule/. [Accessed on September 28, 2019 at 6.34 pm]. 